Vol. 6, No. 2, 2019

https://doi.org/10.23939/eem2019.02.105

UDC 657.412.7(477.8) «18/19»; :005.21

JEL Clasification Code M41, B15, N01

O. Lemishovska

Lviv Polytechnic National University, Ukraine, PhD, Associate Professor

E-mail: leslem@ukr.net

\title{
THEORETICAL-CONCEPTUAL BACKGROUND, METHODICAL APPROACHES AND CRITERIA FOR ESTABLISHING BUSINESS RESULTS IN ACCOUNTING AND FINANCIAL AND ECONOMIC THOUGHT OF GALICIA (SECOND HALF OF THE XIX - FIRST HALF OF THE XX CENTURY)
}

\begin{abstract}
The objective establishment of the level of efficiency (effectiveness) of the functioning of economic entities with the complexity of the architectonics of the economy becomes more problematic, and the system of criteria of efficiency becomes more complex and more debatable. In today's financial and accounting theories and, as a consequence, the practice of financial management, there are a number of debating questions about the system of performance indicators, methods of formalization. This actualizes multi-vector studies both in the accounting field and in the system of interdisciplinary research. The accounting methodology and the specific methodology for calculating performance indicators throughout the evolution of this science have always been based on one or the other financial doctrine. In the article are analyzed some aspects of contemporary financial doctrines and regulatory norms of different institutions that influenced the development of conceptual frameworks and methods of calculating performance indicators in accounting development of scientists of Galicia. The scientific validity of the approaches proposed in this article to improve the current basis of enterprise performance criteria is based on the justification of the use of historically formed ideas in the past in the designated territory and is based on the following postulates: accounting tools are the basic information system of any paradigm of financial results management; the process of forming a system of indicators of real and expected profits should be based on the principle of accounting - the assumption of continuity of the enterprise, which is also embodied
\end{abstract}

in modern concepts of financial management of sustainable development. Using general scientific and interdisciplinary methods of cognition, historicalretrospective and historical-comparative methods, theoretical generalizations of basic principles of accounting practice were conducted and the content of Galicia's accounting opinion regarding the indicators of efficiency in relation to the provisions of the current financial and economic concepts was evaluated. The principles and content of reflecting the profitability of the enterprise in the writings of Western Ukrainian scientists are revealed and analyzed. On the basis of this historical and economic intelligence, an argument is made about the possibility of using some of the workings of Galician theorists in the field of finance and accounting to improve the modern system of performance indicators in accounting, financialanalytical and management theory and practice. In particular, it is proposed to take into account the provisions formulated at the time for evaluating the results of the enterprise based on changes in the capital due to economic factors, approaches to accounting for one-time (occasional) income or losses, and methods for the productive impact of the intangible component of capital on the evaluation of the enterprise efficiency. The proposed is in line with modern concepts of costoriented management, criteria for market-based tools for evaluating the effectiveness of companies.

Key words: financial results, accounting, financial and economic doctrines, institutional environment, Galicia territory, conceptual and methodological developments of Western Ukrainian scientists. 


\section{O. Lemishovska}

\section{Introduction}

The correct establishment of the economic entity's effective performance has been extremely important in all periods of the evolution of financial and economic sciences and accounting. The high significance threshold is associated with the broad operation of indicators of this type in management and regulation processes based on a system of criteria that reveal the efficiency of enterprise functioning. On the basis of one or another system of criteria indicators, for a long historical period, a demonstration of sound financial and economic management of the invested capital was carried out. The objective reflection of a business entity's effective performance in the accounting system has been the primary purpose of this applied discipline throughout its evolution. During the period of accounting thought, many theorists and practitioners have proposed various improvements in conceptual and methodological principles, principles and approaches to accounting for financial results. The work of world-renowned scholars and accounting schools is comprehensively and sufficiently analyzed and evaluated in historiographic sources. In contrast, the development of the theorists and practitioners of Galicia, including and with regard to the object under study, remain almost unexplored, although the individual ideas they formulate may objectively be relevant to improving the modern accounting of financial results and certain provisions of financial, economic and management concepts.

\section{Formulation of the problem}

Financial result as an economic category in all historical periods of financial and accounting science and processes of financial management has been and still remains one of the most important and, at the same time, the most difficult in its content. In general perception, it characterizes a certain kind of positive or negative result of the economic entity, on the basis of which the level of efficiency (inefficiency) of invested (involved) capital, assets and a number of other performance indicators are determined. At present, a considerable amount of research on an international scale confirms dissatisfaction with the relevance and usefulness of information in public financial statements, first and foremost performance indicators - "profit information does not reflect the objective performance of modern companies." Well-known specialist in financial reporting, accounting and finance professor at Stern Business Schol at New York University, Baruch Lev sees as "the failure of accounting standards developers to adopt the traditional model of income statement (compliance) in favor of the balance model (asset valuation)" [ 1], that is, one that was formulated in the past and used for a long historical period in practice. Absence in the modern accounting system of specific methods for formalization of financial results and the presence of many significant achievements in financial theories and accounting concepts during their evolutionary development substantiate the relevance of the article. In the declared period of this study, the works of Galician theorists emphasized on the practical importance of reliable calculation of indicators of effective functioning and development of an objective methodology on the basis of which it was possible to "compare the results of activity of an enterprise for two equal periods in order to establish a developing enterprise or falls" [2, p. 9].

The justification of the relevance of this article is based on the results of the analysis of studies and publications, in which scientists discuss the positioning of financial results and capital in modern accounting and reporting them. At the same time, the results of historiographical sources prove the fact that in the past the development of sufficiently deep ideas of the theoretical and conceptual plan and methodological provisions on the formation of information about profits and losses in the context of accounting for "capital". In both modern and past developments, the problem is that profit is generated by the operation of capital capital both invested in current operations and as a result of growth or loss due to, for example, environmental factors. In the researched developments of the Galician theorists in the declared period the problems of this kind were also solved: "Comparison of balance sheets at the end and the beginning of the year shows an increase in the amount of property growth. This part of the capital is called the net claim [3, p. 64]; "Profit consists of an increase in both property and capital, that is, profit is not only profit of capital, but at the same time, and even first, profit of property ... a separate group is formed by not realized profits, 
which should be called capital reserves for their allocation from realized profit." [4, p. 32, 49]. It is from the point of view of contemporary problems that the conceptual content and methodological orientation of accounting thought in the writings of Galicia's scholars in the period from the second half of the XIX to the middle of the XX century were evaluated.

\section{Methodological approach.}

The methodology of the article is based on general scientific and special methods of scientific knowledge. The choice of research methods is driven by the nature, subject matter and purpose of this historical and economic exploration. The established methodology covers, in addition to the main object, related and interrelated components of research, providing a wide range of disclosure of scientific and applied developments of scientists of Galicia. In order to evaluate the past financial and accounting developments, from the point of view of the present, an analysis of publications concerning the existing problem in the financial concepts and reporting of financial results was carried out. Scientific sources of historiographic character are summarized in which rational aspects of theoretical and methodological plan are revealed and new results of previously unexplored developments of theorists and practitioners of Galicia are presented. On this basis, we obtained a larger information base on financial and economic and accounting opinions during the period under review. The determined spectrum and coordinates of the study determine the use of a systematic methodological arsenal, in which the historical-system method is the basic toolkit.

The process of discovering, analyzing and evaluating conceptual foundations in the researched developments of Western Ukrainian scientists was ensured by the use of retrospective method, formal logic methods and the use of interdisciplinary methods. Taking into account the complexity of isolation of regional studies, the study used scientific and cognitive methods of abstraction and concretization, which provided the opportunity to borrow experience of conducting historical and economic studies of this type. The method of historiographic analysis and the historicalcomparative method have been used for the theoretical and methodological clarification of the processes of formation and evolution of categorical concepts of the time, the content of results in accounting and the impact of financial doctrines on its methodology.

Through the comprehensive use of these methods, a comprehensive study of the various aspects of the content was conducted in accordance with the principles and approaches defined by the JEL Code Classification in the field of scientific and economic research with a focus on the historical tilt of intelligence. The methods selected provide for the processing of material relating to the blocks: M41 Accounting, which is part of the general section M Business Administration and Business Economics (Marketing; Accounting); B 26 - Financsfk economics from block B2 of the Economic Economic Thaght. The chosen methodology is based on the principles of historical and economic research, which made it possible to rationally process the materials in accordance with the provisions of block B - History of Economic Thought, Methodology, and Heterodox Approaches. The approaches used to process materials are consistent with the principles outlined in N9 Regional and Urban History, in particular section B25 - Historical; Institutional; Evolutionary; Austrian from Unit B1 - History of Economy Thougt though 1925, B15 - Historical; Institutional; Evolutionary from the History of Economy Thought block. The proposed, like other studies of historical and economic trends, is based on historiography and source, and therefore selected methods provide the block N01 - Development of the Discipline: Historiographical; Sources and Methods from Group N - Economic History.

\section{The purpose of the article}

The problem that has not been solved to date is the lack of systematic and professionally oriented research of the scientific achievements of Galicia's theorists in the historical past, the introduction of the results obtained in the scientific circulation and the assessment of the possibility of using individual ideas in the modern subject area of knowledge.

\section{An analysis of the latest publication}

Existing problems in trusting the calculated results of the enterprise with the modern accounting system are related to the pressure on the accounting 


\section{O. Lemishovska}

methodology of the latest concepts of financial management, in particular the key performance criteria used in them. Many of these criteria are qualitative, difficult to formalize in the system of evaluating the effective functioning of market economy entities: "general economic categories such as profit (loss) are an abstraction and for their practical application their interpretation is required by accounting" [5, p. 124 ]. Such issues are not new to the accounting and reporting system. For example, given the dominance of certain regional financial doctrines developed within the Austrian School of Economics, the formation of accounting knowledge and the development of theoretical accounting principles by Galicia emphasized the methodological comparison of performance indicators for the comparable periods "during which its activity was equally revealed" 2, p. 9]. The expediency of analyzing the evolution of methods of formalizing indicators of the performance of the enterprise, the assessment of the historical methodological bases of their reflection in different accounting systems produced in the past is noted in many domestic and foreign publications and studies. In particular, the publication [6] argued that "for the development of perfect methods of accounting for financial results, it is necessary to systematize their development in time ... studying the past, you can find solutions for the future" [6. with. 283]. In another paper [7], scholars have taken a similar stance, stating that "the study of the genesis of accounting profit makes it possible to understand the reasons for the need for continuous improvement of accounting to determine the directions of its further development" [7, p. 4].

The importance of using past experience (theoretical development and applied methodology to improve the entire system of modern accounting based on the object of financial results "will allow to reveal the dynamics of the transformation of practical activity in the system of scientific knowledge about methods, principles and methods of determining financial results, to track the change of general concepts and, on this basis, to master the technique of scientific prediction" [8, p. 5]. The feasibility of resorting to development in the territory of Galicia is substantiated in many studies: "in Western Ukraine, which was part of AustriaHungary, and then Poland, economic science was significantly influenced by European thought, and therefore requires further study" [9]; "Today there is no comprehensive picture of economic thought in Western Ukraine, in particular in the sphere of finance, which at that time was based on the world's assets" [10].

\section{Presentation of basic material of the research Overview: a panorama of the basis for accounting thinking.}

In Galicia (a separate province - the crown region of Galicia and Lodomerija in the AustroHungarian times and the corresponding territory in the time of the Second Commonwealth) the basic principles of the German accounting school were used, which were nevertheless adjusted to the content of the doctrines of the Austrian School of Economics and were influenced by development and Krakow schools in Polish economic and financial thought. The dominance of certain basic conventions of business schools in a certain period permanently caused (sometimes significant) influence on methods of calculating financial results in practical accounting (calculation on the basis of assets (change in cost of capital) or comparison by a certain method of income and expenses).

The methodology for calculating financial results in the accounting system and disclosed in public reporting has always been based on the tenets of financial doctrines that have dominated particular government entities in a particular historical period. The financial and economic doctrines have historically formed different notions of profit that, in one way or another, have influenced the methodology of accounting systems: profit as a result of the activity of an economic entity, including changes in the situation; profit as a result of the use of capital; profit as a financial expression of the economic result of an activity (excess of income over expenses). The Impact on conceptual and methodological content of accounting had the personal doctrine (financial results form part of the profit that is calculated at cost of spent funds) and approaches to institutional direction (financial results are a consequence of estimating changes in invested capital at cost) (historical prices)).

In formulating their developments for the Galician theorists in the field of accounting, both the legislative prescriptions and the basic provisions of 
European theories and practices were relevant. First of all, note the work "Balance and tax" [11], which was the basic guide for the organization of practical accounting in the enterprises of the western territory of Ukraine. The basis was the Encyclopedia of Accounting, which, like previous work, was used in Galicia. In these works, the basic basis for the economic expression of productive activity was the definition: "the net profit is the existing property fund, which exceeds the initial contribution, discovered through the balance sheet [12].

The fundamental balance theories have had a significant impact on accounting methodology (theory and practice). From the point of view of the modern economy, the most important can be recognized organic balance theory [13], which generally focuses on the objective calculation of the property status of the enterprise (establishing the reproductive value of the enterprise). At that time, it was believed that this concept provides information management performance, conditional on the principles of the physical concept of capital conservation (the postulates of static balance theory) and financial (basic principles of dynamic theory). According to this theory, it is believed that the formulated property approach with the evaluation of assets at revaluation allows to truly assess the level of performance of the enterprise. The cost criteria of this concept is based on, and the indicators of the Profit and Loss Statement are considered through the calculation of the result of the relative change taken into account (on the balance sheet) of the value of assets [13, p. 5].

In static balance theory [14], the main purpose of accounting was aimed at generating information about the possibility of repayment by the enterprise of its debts. It maintains that the financial results are capital gains of the enterprise during the reporting period. According to this theory, the indicator of effective management of an enterprise is derived, and priority is given to the indicator "net asset value", which is considered as equity.

The financial result in the concept of dynamic balance theory [15] is the basis for it, and therefore the objective repIn the dynamic accounting accounting paradigms developed on its basis, the calculation of financial result lies in the field of extended income recognition, including, in addition to the actual sales, potential sales.resentation of this indicator in the financial statements is the main purpose of the accounting system. The concept of dynamic accounting is aimed at measuring (establishing) the efficiency of the enterprise, where the financial result is a change over a certain period of the amount of capital invested in the enterprise, which can be caused only by the financial and economic activity of the enterprise).

An important source is the source of activity of the Galician Regional Finance Directorate (Galizishe Finanz - Direktion in Lemberg, Galacyjska Krajowa Dyrekcja Skarbu we Lvowie), the documents of which are kept for the period 1773 to 1928 in the Central State Historical Archives of Ukraine in Lviv (fund 160, sp. 7908). In the name given, this directorate was created in 1850 instead of the liquidated Office of State Revenue. Therefore, the instructions in the Ministry of Finance and the Governorate's instructions on matters within the competence of the Directorate are important. From the point of view of the topics discussed in this study, the content and nature of the indicators that were recognized as the main ones in determining the results of the activities of the state and commercial economic entities of that time are important. These are set out in the Activity Reports and Financial Statements of State Property and Various Enterprises.

Another important source for the study of this subject is the documents of the State Accounting (K.k. Staatsbuchhaltung in Lemberg; C.K. Ksikgowons panstwowa we Lwowie). This public accounting was created as early as 1773 to account for income from the estates of state, religious and public funds, state salt pans, etc. Its function included controlling the payment of taxes of all kinds, county taxes, state duties, as well as auditing the financial accounts of enterprises, institutions and institutions. Replacing the public accounting department with the newly created Financial Department of the Office of the State did not essentially change its functions. In the funds of the Central State Historical Archive (f. 187, ref. 4737) numerous documents for the period 1774 to 1866 are stored, on the basis of which it is possible to draw conclusions about the existing regulated regulations to determine the results of activity of economic 


\section{O. Lemishovska}

entities of different kinds of activity and their taxation.

The formation of methodology in the system of accounting for determining financial results was strongly influenced by the activities of the District Chamber of State Control, founded in the Polish period in Lviv (1920) (Okrkgowa Izba Kontroli Pacstworoej we Lwowie). Its functions included auditing the state (accrual, payment) of state revenues in the territories of Lviv, Stanislavsky, and Ternopil voivodeship. Given that in different spheres of economic and economic activity accounting methodology had its specificity in determining the size of profits, then the group of controllers (auditors) of this institution were different. One of the departments carried out checks (audits) of the accrual of income and the payment of taxes from institutions belonging to the ministries of railway, industry and trade. The second department audited the correctness of accounting and monitored the payment of income taxes by institutions under the jurisdiction of the Ministries of Finance, Post, Broadcasting and Agriculture, ie enterprises with the organization of accounting "budgetary institutions". A similar function was the Finance House (Izba Skarbowa we Lwowie), which operated from 1919 to 1939. She was responsible for overseeing the activities of financial institutions, executing the state budget, and making decisions in tax matters (establishing the reliability of turnover and income taxes, etc.). The acts of financial audits conducted by this state institution, as well as balances and financial reports and materials on the collection of property and income taxes, preserved in the archival funds (f.161, spr.79091), testify to the sufficiently strong influence of this institution on the method of calculating the financial results of budgetary institutions.

The documentary acts on the control of financial and economic activities with the access to confirm the accuracy of the calculated financial results, saved in the funds of the Central State Historical Archives of Ukraine in Lviv (Fund 803, p. 17112), allow for a wide analysis of the methodology of calculating the effective activity at the enterprises of different spheres economic activity, and to conclude on the state regulation of accounting. The importance of objective accounting by the accounting of the results of business activity is confirmed by the materials of the audits and audits of that time. According to state regulations, such audits were conducted by Audit Unions (public associations), which were delegated to the functions of state control. The object of financial results (definition and distribution) was essential in the processes of conducting both external audits and internal audit services (control commissions), which were a mandatory structure of the supervisory boards of cooperative associations.

\section{Conceptual and methodological landscape of accounting concepts in architectonics of financial and economic doctrines}

The content and the functional orientation of the theoretical and methodological foundations in the field of accounting knowledge of Galicia has been inextricably linked to the imperatives in the financial sphere and influenced by the dominant economic doctrines over the studied historical period. A retrospective analysis of the evolution of accounting thought (theoretical concepts of accounting science) of Galicia also shows that the focus of scientific development of the scientists of the region was in the parameter of architecture of the then doctrines of the Austrian School of Economics and the German School of Accounting. Given the high importance of the criteria for the effective functioning of economic systems, the relationship and interplay of accounting conventions and financial and economic doctrines is the most obvious object of financial results. European acquisitions directly in the field of accounting were also taken into account by Galicia's theorists in their developments, widely introduced into the scientific turnover. For example, the concept of "dummy (fictitious) profit (Scheingewinn)" produced within the German school of accounting, that is, profit is obtained through the galloping rise in prices, the danger of which is its taxation [15]. Based on the use of interdisciplinary expertise, economists of the region justified, for example, the higher objectivity of reflecting only the current consequences of economic activity on the main accounting performance accounts, and the incidental income was proposed to be attributed to capital accounts. In general, it can be noted that in the system of various types of financial and economic doctrines for establishing the efficiency of economic entities, an 
important place was given to accounting science: "determining the consequences of a particular economic activity is the task of accounting science" $[2, \mathrm{p} .1]$.

At the level of contemporary (recent) development of financial and economic and accounting profile was the Polish Economic Society in Lviv (Polskie towarzystwo ekonomiczne we Lwowie). Its purpose was to develop economic, financial and accounting sciences, to promote and bring into the circulation of the leading European and world economic assets. The territorial branches of this society were the Krakow and Lviv scientific schools, whose members made significant contributions to the development of accounting thought. In this context, we briefly indicate the contribution of members of these schools, natives of Galicia. An example is the development of Głabiński Stanisław, one of the founders of the Lviv Science School in Polish economic and financial thought. This scholar (Professor of Political Economy, University of Lviv, Assistant Professor of Public Economics, Economic Policy and Statistics at the District Department of arable schools in Dublianu) has formulated a number of provisions on taxation, statistics and the principles of social value in his scientific work. At the heart of his concept was the concept of economic self-sufficiency, where accounting approaches to information support performance indicators played a significant role in managing the economy. The main provisions of his scientific works (Wyklad nauki skarbowej (1894), Wyklad ekonomiki spolecznej (1913), Nauka skarbowosci (1925)) are found in the formulated works on accounting.

The representative of the Lviv School in Polish Economic and Philosophical Thought was Professor of the Department of Political Economy and Administrative Law, Dunajewski Julian Antoni of the University of Lviv. This scholar, as an adherent of classical political economy, in his writings relied on the basic principles of historical and Viennese schools. On the basis of some provisions of these schools, he introduced into the economic literature of the Galician scientific environment the concept of "principle of economy", the essence of which was to obtain the highest possible result from the standpoint of the theory of marginal utility (source of profit justified the difference between present and future value). The conceptual-categorical apparatus formulated in the scientific works of the scientist (Ziemia i kredyt (1864-1869). Wyklad ekonomii politycznej (1935)) found a place in the development of accounting (for example, 2, 3, 4, 17, 18). The same can be said about use in the field of accounting of scientific provisions Czerkawski Wlodziemerz Aleksander, the founder of the Krakow School of Polish Economic and Financial Thought. From the point of view of the subject of our study, we will show that the scientific views and provisions of the theoretical and methodological positions of the Austrian (Viennese) school in economic theory, this scientist outlined in the works "The theory of pure land income" (Teoria czystego dochodu z ziemi, 1893) the importance of large farms in social economy "(O znaczeniu wiekszych gospodarstw w ekonomii spolecznej, 1896)," The initial foundations of the organization of public economy "(Naczelne zasady organizations gospodarstwa spolecznego, 1898). His scientific theory of value, marginal utility, and capital income was the basis for formulating some of the conventions of Galician economists.

Regarding Bukovina as a constituent of Galicia, let us point out that the departments of political economy and statistics functioned at the Classic University of this territory (Chernivtsi University). Famous scientists taught at these departments - Friedrich Kleivehter, Joseph Aloise Schumpeter, S. Smal-Stotsky. The scientific direction of Professor of Political Economy F. Kleinwehter (since 1932. Lecturer at Harvard University) was to study the peculiarities of the organization of production and the development of fundamental approaches to measuring its effectiveness. His research papers "On Social Insurance with Particular Consideration on Its Relationship with Trade and Financial Policy", "Fundamentals of Agricultural Training", and his study (course) study "Analysis of the BémBeverkemian Economic Resources" also had an impact on improving the accounting methodology for establishing the results of enterprises (primarily through the development of costing systems).

S. Smal-Stotsky's scientific activity and the applied application of the provisions obtained therein had a direct impact on the content of practical accounting in credit-cooperative 


\section{O. Lemishovska}

cooperative associations, in particular on the procedural and technical methodology of establishing the effective activity of credit unions and the distribution of profits therein (within unions "Russian Checkout" and "Peasant Checkout"). It should be noted that in the same context, the wellknown scientist of the German accounting school IF Cher in the above-mentioned work "Accounting and Balance" argued that a rational and sound methodology for "organization of accounting at the enterprise can affect its profitability and development as much as any innovation in technical equipment and enterprises" [16].

In the territory of Western Ukrainian lands the scientific activity of J. Schumpeter, which is considered one of the most prominent scientistseconomists, was formed. The theoretical heritage of this scholar is extremely wide and varied, and in various contexts described in numerous historiographical sources. According to our study, we briefly state his view as an Austrian School of Economics representative in accounting, including the relationship between the provisions on financial performance in financial and economic doctrines and accounting opinion. He articulated accounting science as an "elevated monument", in particular with respect to an object he called "cost-profit calculus". Recognizing this system as an effective tool through which the economy "powerfully drives the logic of the enterprise." A number of provisions in J. Schumpeter's writings indicate that he had a good understanding of the conceptual and methodological foundations of the accounting system and considered it an integral part of economic science: "how many entangled disputes would have been avoided had economists adhered to the accounting values of term and capital." His works, The Essence and Basic Content of Theoretical Economics, and The History of Economic Analysis, had a significant influence on the formation of accounting thought.

On the basis of the newest financial and economic doctrines for this time that the accounting scientists of Galicia challenged the basic principles of accounting methodology of calculating financial results, developed in the world of accounting science: "all the views and definitions presented cannot meet economic principles. The profit and loss account is not an intermediary but a capital account and not a property account; it is also not a profit account but a net stock account. Net income is the balance of the capital gains in the balance sheet" [4, p.121]. It should also be noted that the approach used in this theory is most consistent with the modern concept of value-oriented accounting.

The personal content of the resultant account is quite clearly expressed in [11], on the basis of which in many cases theoretical provisions have been formulated to improve the practice of accounting and in the enterprises of the western territory of Ukraine: "The profit and loss account is the intermediary between the stock performance accounts and the net performance account, which transfers the balance, that is, the net profit, to the capital account" [11, p. 110]. In an accounting encyclopedia [12], similar to previous work used by Galicia's enterprises at the time, the authoritative scholar in accounting R. Stern positions "the profit and loss account, as well as the income and expense accounts, with respect to changes in property accounts" [12, with. 224]. Therefore, the account, which determined the financial result of the enterprise, occupied a different disposition in the scientific development of Galician scientists. To confirm the relationship between conceptual principles of accounting and economic theories, we point to the content of a scientific textbook [17], which in section 1 "Principles of social economy related to the study of accounting" (Rozdział I. Zasady economii spolecznej, pozostajzku w wwi z nauka rachunekowósci), shows the effect of losses on assets (Wplywy ubytków należylości on the flat majątku).

The extension of the "accounting thought" of Galician scholars was influenced by the position of the French accounting school (economic slope). Distinctive aspects in the method of calculating financial results (profits in their traditional sense income minus expenses) took place in the accounting system of the Concern of the French oil industrial and trading companies "Maiópolska", ("Maiópolska". Lwowie). This concern extended its "general accounting policy" and, above all, the method of calculating financial results (income, profits and expenses) in the practical accounting of its mining and oil companies and companies ("Alfa", "Basta", "Gopio", "D" Browa, Eqvivalent, Petrolea, Premier, etc.). The purely accounting 
documents (the Fund 225, Case 5389 for 1885-1940 of the Central State Historical Archives of Ukraine in Lviv) make it possible to conclude that some of the features of the French School of Accounting have been used at the enterprises of the oil industry of this concern. The French oil company Putroles de Potok (Fund 258, right) followed a similar approach to accounting for the results of operations from 1909 to 1926.

The influence of the French accounting school in particular refers to the method of separation in the accounting system by enterprises of the contingent and incidental income (profits). The following also applies to the methods of profit sharing, which, according to customary traditions for business entities in Galicia, have been more widely used to create different types of reserve capital than is the case in French accounting. The financial statements and balance sheets of the companies testify to the wide information spectrum of disclosure of sources of income. The development [17] against the background of the general certificate of turnover and income (in the original statement "Zeznania o obrocie $i$ dochodzie") gives an example of the closing of shares and distribution of net profit in a joint venture (in the original statement "Przykład: zamknięcie rkowe i podział i podział i podział i podział zysku w spółce jawnej").

In the econometric balance theory, formulated in the Lviv scientific environment, the account of financial results by economic content and structure is represented by a stock account: "the account of profits and losses is not an intermediary (the author's note: here it is meant - it is not calculated because of the difference of purchase and sale value values), and directly to a capital account, it is also not a net account but a net stock account. The net profit shown in the balance sheet reflects the growth of capital assets" [4, p. 121]. In this theory, the profit and loss account, which accumulates information about the results of the enterprise, is considered in the group of capital accounts. At the same time, on the basis of econometric equations (econometric quadriga, econometric octagon), transformation and accommodation (adjustment equilibrium of values) of property and capital are ensured. That is, this balance theory holds the trunk position that the presentation of the result of working capital, although reflected in the income statement, but by the method of transferring profits or losses to this account from other accounts.

Determination of the resultant activity of economic entities due to the change of property status was dominant in the works of Galician theorists at that time: "Comparison of balance sheets at the end and the beginning of the year shows an increase in the amount of property growth. This part of the capital is called the net claim [3, p.64]. This position and the corresponding methodology regarding the theoretical and conceptual foundations of the accounting system of the results of the activity of the enterprise is also observed in educational and theoretical work [17], where it is justified in such a way that provides budgeting and economic plan ("Plan gospodarczy czuli budżet").Data on changes in the state of property ("Ó zapisywaniu zmian majątkowych w porządku chronologicznym według metody kameralistyczcznej, czyli o certzebie prowadzenia dzienników") are considered as informational tools for external users, ie, they are in the nature of reconciliation with the agreement.

The methodological arsenal of analysis of the income statement (in the original statement "Analysis of rachunku strat i zysków") is proposed in development [18] with guided practical examples analytical processing rezultatnyh accounts (in the original statement "Praktyczne wzory analitycznego opracowania zamknięć rachunkowych") to objectively calculating the annual income to be taxed ("Obliczenie dochodu rocznego, podlegającego opodatkowaniu").

In developing [4] the results of the activity of the company are disclosed in a very wide range, in particular formulated and substantiated in the author's editorial Scheme eines Vermögenskontos in relation to the proposed structure of the capital account (Schema eines Kapitalkontos). In their development, a more favorable income statement (Das Gewinn- und Verlustkonto) has been developed for the national economy. This report proposes substantially new principles for the calculation of net income or loss, which were argued to be more relevant to current practice(Die Berechnung des Reingewinnes oder Verlustes in der Praxis) On the basis of the tools of econometric science proposed "Correct calculation of net profit"(Eine richtige Berechnung des Reingewinnes). 


\section{O. Lemishovska}

\section{Conclusions}

In modern accounting science, the view is that its development should be based on an interdisciplinary basis. The soundness of the basics of such development can also be ensured by gaining knowledge of accounting history, in particular the principles of harmonization of accounting conventions and the provisions of financial and economic doctrines that have taken place in the Galician economic environment during the period under review.

\section{References}

1. Baruch, Lev, (2018). The deterioration usefulness of financial report information and how to reverse it. Accounting and Business Research, 48 (5), 465-493.

2. Moralevych, Ya. (1924). Osnovy rakhunkoznavstva (lektsii na kooperatyvnykh kursakh ukrainskoi selospilky). Fundamentals of Accountancy (lectures on cooperative courses of the Ukrainian villageunion). Terezyn: Pid zaradom upravy kursiv Ukrainskoi selianskoi spilky v Ch. - S. - R., 12 s.

3. Bezkrovnyi, K. (1932-1933). Torhovelne rakhivnytstvo: (kurs lektsii). Podiebrady: Ukrainskyi Tekhnichno-Hospodarskyi instytut pozaochnoho navchannia $v$ Podiebradakh (Chekhiia). Trade accounting: (course of lectures). Poděbrady: Ukrainian Techno-Economic Institute for Extraordinary Studies in Poděbrady (Czech Republic). 201c.

4. Ciompa, P. (1910). Grundrisse einer öekonometrie und die auf der Nationalökonomie aufgebaute natürliche theorie der buchhaltung; ein auf Grund neuer ökonometrischer Gleichungen erbrachter Beweis, dass alle heutigen Bilanzen falsch dargestellt werden Verlag des Handelsschulvereines in Lemberg. Lemberg: Druck von Artur Goldman in Lemberg,

5. Maliuha, N.M. (2004). Prybutok yak ekonomichna kategoriya ta object buchalterskogo obliku [Profit as an economic category and an object accounting] Visnyk Zhytomyrskoho derzhavnoho tekhnolohichnoho universytetu - The Journal of Zhytomyr State Technological University, 2, 119129 [in Ukrainian].

6. Berdnikova, T.M. (2011). Evolutsia rozvytku $i$ analizu finansovykh rezultativ. [Evolution of the development of accounting and analiysis of finaacial results]. Naukovi pratsi Kirovohradskoho natsionalnoho tekhnichnoho universytetu. Ekonomichni nauky - The Collection of Scientific Works of Kirovohrad National Technical University. Economic Sciences, 20(1), 283-290 [in Ukrainian].
7. Yancheva, L.M., Chernikova, I.B. \& Kuznetsova, S.O. (2012). Oblikovo-informatsijna systema upravlinnia prybutkom torgovelnykh pidpryiemstv [Accounting and information system of prof managements of trad enterprises]. Kharkiv: Kharkivskyi derzhavnyi universytet kharchuvannia ta torhivli [in Ukrainian].

8. Pushkar, M.S., Havryshko, N. V. \& Romaniv, R. V. (2003). Istoria obliku ta kontrolu hospodarskoi dialnosti [History of accounting and eontrol of economic activity]. Тернопіль: Ternopil: Kartblansh [in Ukrainian].

9. Shayner H. I. (2012). Rozvytok komertsiinoi osvity na Zakhidnoukrainskykh zemliakh (druha polovyna XIX - persha tretyna XX stolittia) [Development of commercial education on West Ukrainian lands (the end of the XIXth and the first third of the XXth century)]. Extended abstract of candidate's thesis. Ternopil: Ternopil national V. Hnatiuk pedagogical university [in Ukrainian].

10. Shafranska I. B. (2015). Ekonomichna dumka Zakhidnoi Ukrainy ostannoi tretyny KhIKh pershoi tretyny Khkh stolittia [Economic thought of Western Ukraine in the last third of the XIX - the first third of the XX century]. Extended abstract of candidate's thesis. Kyiv: SHEE «Kyiv National Economic University named after Vadym Hetman» [in Ukrainian].

11. Reish R., Kraibih, K. (1907). Balance and tox Viden

12. R Stern (1902) Encyclopedia of Accounting,Viden $i$ Leiptsih

13. Schmidt F., 1922. Die organische Bilanz im Rahmen der Wirtschaft (zweite, durchgqsehene und erweiterte Auflage). Verlagsbuchaltung in Leipzig: G.A. Gloeckner.

14. Simon G., 1899. Di Bilalanzen der Uftigenfellitaften. German Veit Simon. Berlin.

15. Schmalenbach E., 1931. Dynamische Bilanz-Funfte Auflage. G.A. Gloeekner, Verlagsbuchhandlung in Leipzig.

16. Sherr I. (1925). Buhgalteriya i balans [Accounting and balance] (2nd ed.). (S.I. Cederbaum, Trans). N.S. Lunskoy (Ed.). Moscow: Publishing House "Economic Life" [in Russian].

17. Sciborski A. Podręcznik do nauki rachunkowości ogólnej i państwowej / Aleksandr Sciborski; opracowany wedlug wykladów radcy Dworu Tadeusza Klusik-Orzechowskiego na c.k Uniwersytecie we Lwowie, cześć I. - Lwów: nakladem wydawcy: $z$ drukarni szcęsnego bednarskiego we lwowie, 1912. - 500

18. Góra W. Bilanse. Studja ekonomiki prywatnej / Witołd Góra. - Lwów - Warszawa: Ksiażnica t-wa Nauczycieli szkót wyżsżych, 1920. - 215 s. 